\title{
A BREXIT TANULSÁGAI A HUXIT SZÁMÁRA
}

Az Egyesült Királyság távozása az Európai Unióból elörevetitette mindazokat a problémákat, amelyekkel az integrációt elhagyó bármelyik tagállamnak szembe kell néznie. Magyarország esetleges kiválása legalább annyi megoldandó bonyodalmat jelentene, mint a brexit, ráadásul az Egyesült Királysággal ellentétben nem a világ ötödik legnagyobb gazdaságaként találná szembe magát velük.

A kiválási folyamat, a brexit pontos menete harminchat hónap alatt sem tisztázott, a bizonytalanság pedig a legerősebb gazdaságokat is térdre kényszeríti. Az Európai Unió elhagyása a lisszaboni szerződés alapján a kiválásról való értesítéssel kezdődik, majd a feleknek két év alatt megállapodásra kell jutniuk a tagság megszűnésének feltételeiről, valamint a jövőbeli kapcsolatokról. Csakhogy a jogi kötöttségek megszűnésének pillanatáig az unió nem tárgyal a jövőbeli kapcsolatokról, kötelező érvényü jogi megállapodás helyett csupán politikai nyilatkozatban foglal állást. Ez érdemben nem csökkenti a bizonytalanságot. A kiválási szándék pillanatában a tagállami valuta értéke csökken, ami versenyképes, az unió irányába nyitott exportszektor esetében mind az uniós tagállamok, mind a további harmadik országok irányába növelheti az export mennyiségét (előbbieknél a kiválásig), azonban az import drágulásával az infláció rövid távú emelkedéséhez vezethet. A brit példa azonban rámutatott arra, hogy az exportelőnyök kiaknázása korántsem egyértelmü, hiszen a bizonytalanság miatt a vállalati szektor a többletjövedelmet nem beruházásra fordítja, hanem inkább tartalékképzésre.

A brit kiválásról szóló tárgyalások alatt az egyik leginkább szemmel tartott gazdasági mutató a müködőtőke-beruházások szintje volt. A bizonytalanság ezen a területen járt a legérzékenyebb veszteséggel, hiszen a kiszámíthatatlan gazdasági kapcsolatok a beruházási döntések elhalasztását és felfüggesztését okozták, elsősorban a gépjármügyártás és az összetett gyártási folyamatokat igénylő elektronikai termékek piacán.

https://doi.org/10.47630/KULG.2019.63.5-6.27

Gálik Zoltán, egyetemi docens, Budapesti Corvinus Egyetem, Nemzetközi Tanulmányok Intézet. E-mail: zoltan.galik@uni-corvinus.hu 
Egy pillantást vetve Magyarországra (is), a kiválás megszünteti azokat az uniós költségvetési transzfereket, amelyeknek jelenleg nettó haszonélvezői vagyunk. A közös politikák közül a mezögazdasági, a kohéziós és a regionális támogatások elvesztése jelentené a legnagyobb érvágást. De az unió fontos célja, hogy a költségvetési források elosztásakor a közös kutatás- és fejlesztéspolitika is egyre jelentősebb szerepet kapjon. A kiválás ezeket a forrásokat szintén komolyan veszélyezteti, hiszen a brexit nyilvánvalóvá tette, hogy a programokban való jövőbeli részvétel a politikai szándékon túl a költségvetéshez való folyamatos hozzájárulást egyértelmüen szükségessé teszi.

Az Egyesült Királyság kilépése a népszavazást követő harmadik évben sem tette világossá az alapvető kérdést, amellyel az uniót elhagyó valamennyi országnak szembe kell néznie: mit is jelent pontosan a kilépés? Jogilag egyértelmü: az uniós szerződések elhagyása. Azonban az új kapcsolatok kiépítése a „puha” és „kemény” kilépés közötti dilemmát hozza el.

\section{Puha huxit}

Bár jogilag nem létezik puha és kemény kilépés (hiszen a kilépés a jogok és kötelezettségek megszűnését jelenti, az azt követő viszonyrendszer pedig csak új nemzetközi szerződés alapján alakulhat ki), a „puha” kilépés a közös piachoz való hozzáférés megtartása igényét jelenti, amely akár a vámunió további fenntartásával is járhat.

A közös piachoz való hozzáférés olyan kötelezettségekkel jár, amelyek nagyon közel állnak a tulajdonképpeni tagsághoz. Az Európai Gazdasági Térséghez (EGT) való csatlakozás, amely az Európai Szabadkereskedelmi Társulás (European Free Trade Association, EFTA) tagságán keresztül érhető el, ilyen hozzáférést biztosít. Az EGT-szerződés magában foglalja a közös piac négy szabadságának elfogadását, azaz az áruk, a szolgáltatások, a tőke és a személyek szabad áramlásának biztosítását. A világ legnagyobb egységes piacának elérése pedig megköveteli a jelenlegi EGT-országoktól a költségvetési hozzájárulást. Egy puha huxit esetén ez alól Magyarország sem lenne kivétel, ha netán ilyen irányt venne a kereskedelempolitika.

A szuverenitás teljes visszaszerzése szempontjából fontos kérdés az Európai Unió Bíróságának a joghatósága alól történő teljes kilépés. Kétpilléres intézményi felépítésével az EGT-modell lehetőséget ad az önálló döntőbíráskodásra, azonban a közös piacot érintő kérdésekben az Európai Unió Bírósága továbbra is megha- 
tározó maradna. Az EGT-tagság lehetővé tenné, hogy az ipari termékek továbbra is szabadon áramolhassanak az uniós tagállamok irányába, ez azonban csak akkor lehetséges, ha Magyarország változatlan formában megtartja az uniós piaci szabályozásokat és dinamikusan igazodik az újonnan bevezetendő szabályokhoz is. Márpedig a piaci szabályozások bevezetése szempontjából nem lehetnek illúzióink, hogy az unió a jövőben a piaci erőfölényét maximálisan kihasználva diktálná az alapvető szabályozási feltételeket. A jóval 70 százalék fölötti külgazdasági nyitottság az EU irányába szükségessé teszi, hogy Magyarország folyamatosan hozzá tudjon férni az egységes piachoz.

Az EGT-tagság lehetővé tenné, hogy a Magyarország számára is kulcsfontosságú termékláncok ne szakadjanak meg. A brexit már most is az egyik legtöbb negatív következménnyel fenyegető következménye, hogy a bevezetendő határellenőrzés megbénítja a fejlett iparcikkek termelési folyamatait. A vámunióban való részvétel (amely nem feltétele az EGT-tagságnak) könnyebbé tehetné a határellenőrzést, azonban a származási bizonyítványok ellenőrzése lelassíthatja a folyamatot. A brexittárgyalások során a brit fél „kreatív megoldások” bevezetésére biztatta az uniót, azonban a határok átlépése előtt vagy után történő vámellenőrzések rendszerének pontos technikai meghatározása nem történt meg. A határokon történő késlekedés rendkívül kiszolgáltatott helyzetbe hozhatja a just in time-rendszerben müködő vállalatokat, legfőképpen a jármügyártókat. Az Egyesült Királyság exportja az EU irányába 2017-ben 44 százalékot tett ki - ez Magyarország esetében 81 százalék. Vagyis Magyarország sokkal sebezhetőbb, a vámellenőrzés az ipari export bázisát adó gyártók csaknem mindegyikét fenyegetné.

Ami igaz az iparcikkekre, nem igaz a mezőgazdasági termékekre. Az EGTszerződés nem teszi lehetővé a mezőgazdasági termékek szabad kereskedelmét az EFTA és az uniós tagállamok között. Az unió elmúlt hatvan éve pedig pontosan rámutatott arra, hogy a külső, harmadik országokkal folytatott tárgyalások és kereskedelmi megállapodások rendkívül korlátozottan biztosítják csak a hozzáférést ehhez a Magyarország számára fontos piaci szegmenshez (igaz, ez a szektor 2017ben csak a bruttó hazai termék 3,3 százalékát hozta létre). Az EU által előszeretettel alkalmazott kvóták és vámok bevezetése a magyar mezőgazdaság számára súlyos következményekkel járhatna.

A személyek szabad mozgásának fenntartása a schengeni egyezményben való változatlan részvételt is szükségessé teszi, ami újabb területen jelenti az uniós szabályozások maradéktalan átvételét és következetes alkalmazását. 
A négy szabadság egységes kezelése a brit tárgyalások során is elsődleges prioritása volt az uniónak, ezen a területen várhatóan egy huxit esetén sem lehetne megbontani az uniós tagállamok szempontrendszerét. Azaz a puha huxit ugyanabba a helyzetbe sodorhatja Magyarországot, mint amitől annyian tartottak az Egyesült Királyságban a brexit kapcsán: külső országként a továbbiakban nem férhet hozzá az uniós döntéshozatali rendszerhez, ugyanakkor korlátozott piaci elérés mellett is teljes mértékben igazodnia kell az uniós jogszabályokhoz, piaci szabályozáshoz; mégpedig úgy, hogy a megfelelő költségvetési hozzájárulást sem lehet megspórolni.

A vámunió fenntartásának kérdése egy másik dilemma elé állítja a kilépni szándékozó tagállamot. A vámunióban való részvétellel a tagállam ugyanis a Kereskedelmi Világszervezetnek az Európai Unió számára kialakított kedvezményes vámtarifarendszerét használhatja. A vámunió elhagyása egyrészt a termékekhez kapcsolódó származási bizonyítványok bevezetését és alkalmazását jelenti, ami az adminisztratív költségek jelentős növekedésével járhat, ugyanakkor szükségessé tenné az új vámtarifa-kedvezményekről szóló rendszer tárgyalását és kialakítását harmadik országokkal. A brexit jó példa volt arra, hogy a kvóták megosztása korántsem automatikusan történik, a kívülálló országok jogot formáltak új feltételrendszer kialakítására. Ez sokkal nehezebb feladat egy olyan közepes-kis ország számára, mint Magyarország.

\section{Kemény huxit}

A „kemény” kilépéssel az uniós jogok és kötelezettségek megszűnnek, nem történne meg a közös piachoz való hozzáférés kialakítása, sem a vámunió fenntartása. Ebben az esetben a határellenőrzés bevezetése miatt a termékláncok egészen biztosan megszakadnának, a vámuniós tagság megszűnése pedig az adminisztrációs költségek növekedésével járna -elsősorban a származási bizonyítványok beszerzése és ellenőrzése miatt. Az uniós intézmények és szabályozások elhagyása azonban továbbra sem jelentene teljes szakítást, hiszen bármilyen termék vagy termékcsoport bejuttatása a közös piacra megkövetelné az uniós szabványok és szabályok átvételét, azok következetes és tartós alkalmazását. Bármilyen szerződést köt is a kilépő ország a jövőbeli kapcsolatokról az unióval, a vitarendezési mechanizmus uniós oldalán továbbra is az Európai Unió Bírósága állna.

A kemény huxittel az áruforgalom mellett a szolgáltatások sem érnék el akadályok nélkül az EU egységes piacát. Az úgynevezett útlevél-jogosultság megszűnése a hazai pénzintézetek számára szükségessé tenné az egyenértéküség elve alapján 
történő igazodást, amelynek jelentős többletköltségei vannak, így csökkentheti a pénzügyi szervezetek versenyképességét az uniós piacokon. A brexit egyértelmüvé tette, hogy az uniós tagállamok területén szolgáltatásokat nyújtó szereplők kötelesek lesznek az uniós szabályozásokat maradéktalanul betartani, és a tagállamok területén alapított vállalatokkal müködhetnek.

A schengeni egyezmény (egészen pontosan az uniós jog e fejezeteinek) elhagyása a határellenőrzés visszaállításával jár, miközben Magyarországnak három schengeni szomszédja (Szlovákia, Ausztria és Szlovénia) és két schengeni tagjelölt szomszédja van (Románia és Horvátország). Harmadik országként a határellenőrzések miatt a turista- és az üzleti forgalomban is jelentős lassulás várható, hiszen a vámellenőrzések mellett az átkelés a nem schengeni partnerországok számára kialakított folyósokon történhet. Külön megállapodás híján az Európai Unióban újonnan bevezetendő ki- és beléptetési rendszer az uniós országokba történő belépés szándéka esetén megköveteli az előzetes regisztrációt és a kapcsolódó díj befizetését.

A teljes szakítás az Euratom elhagyását is magával hozná, így a közös nukleáris kutatási programokban való részvétel szintén meghiúsulhat.

\section{A hosszú távú együttmúködés kérdőjelei}

Az Európai Unió a világ legnagyobb nemzetközi szerződésrendszerét építette ki. Az unió elhagyása egyben a nemzetközi szerződések megszűnésével jár. Az együttműködési megállapodások, a szabadkereskedelmi és társulási egyezmények fenntartása óriási kihívások elé állítja a kilépő országokat. A nemzetközi szerződések újratárgyalása olyan szakértelmet kíván, amely a kilépő tagállamok számára nem adatik meg, hiszen a nemzetközi gazdasági szerződések megkötésével kapcsolatos feladatokról az unió képviselői, szakértői tárgyaltak.

A kilépő tagállamnak egyrészt tisztáznia kell a viszonyát az Európai Unióval, másrészt a harmadik országokkal. Az unióval való kapcsolatok kialakítása időben elhúzódhat, hiszen a kilépő tagállam számára az integrációnak nincs modellszerzödése. Az EU külkapcsolati rendszerében eddig különböző típusú és tartalmú szerződések készültek a preferenciális és a nem preferenciális országok számára, azonban egyik sem alkalmazható maradéktalanul sem az Egyesült Királyság, sem egy lehetséges további kilépő számára. Alkupozíció szempontjából pedig kétség sem férhet ahhoz, hogy a közös piaci hozzáférés igénye esetén az unió következetesen alkalmazni fogja az összes uniós szabályozás fenntartását. Mindemellett az EFTA-orszá- 
gokkal való viszonyt is újra kell tárgyalni, hiszen a továbbiakban az EGT-szerződés nem lenne érvényes.

Hasonlóan összetett feladat a külső országokkal történő megállapodás. A kilépő tagállam ezen a területen is kedvezötlenebb alkupozícióban kerül, mint az (Egyesült Királyság nélkül) 440 millió lakosból álló EU. A világ fejlett országaival a nem preferenciális szerződések újrakötése változatlan feltételekkel a jelentős gazdasági teljesítménybeli különbségek miatt nem valószínű és nem is kívánatos. A preferenciális szerződések újrakötése azok jellegéből és földrajzi irányultságuk, valamint a kevesebb átfedő érdek miatt sok esetben erősen megkérdőjelezhető. A migrációs területeket érintő paktumok újratárgyalására is szükség lehet, hiszen ezek automatikus kiterjesztését a változó feltételrendszer nem tenné lehetővé. A harmadik országokkal történő kereskedelmi és politikai kapcsolatrendszer újraértelmezése mindaddig nem lehetséges, ameddig nem történik meg az unióval való kapcsolatok jellegének tisztázása, hiszen a külső országok befektetési döntéseit nagyban befolyásolja, hogy a kilépő állam területéről miképp lehet elérni az EU egységes piacát.

A gazdasági együttműködés kereteinek kialakítása mellett az uniós együttmüködések közül a közös kül- és biztonságpolitikával való viszonyt is tisztázni kell. Az EU a lisszaboni szerződést követően kialakította az Európai Külügyi Szolgálatot, amely jelentős képviseletet adott a világban az uniónak, amit a kilépés után a kiszakadó állam nem tud megtartani. Az EU Közös Biztonság- és Védelempolitikájához való viszonyt külön szerződésben kell meghatározni. Különösen fontos az új típusú kezdeményezésekben való részvétel fenntartásának kérdése (a megerősített együttműködés, az új védelmi ipari kezdeményezések).

\section{Az új gazdasági kormányzási rendszer elhagyásának következményei}

A világgazdasági válság következményeinek kezelésére az Európai Unió új gazdasági kormányzási rendszer kiépítésével válaszolt. Az aszimmetrikus sokkokra adható válaszok a lisszaboni szerződést követően kiépített intézmény- és szabályozórendszer révén csökkentik a gazdasági válságok kialakulásának vagy elmélyülésének kockázatait. Az EU elhagyása egyben ennek a védőernyőnek az elhagyását is jelenti, amely fokozza a volt tagállam világpiaci kiszolgáltatottságát.

Az új rendszer magába foglalja a tagállami költségvetési tervezés és kivitelezés, valamint a pénzügyi szektor folyamatos ellenőrzését, a beavatkozásra használható intézményrendszer és a pénzügyi eszközök létesítését. A mechanizmusok egy ré- 
sze csak az euróövezeti tagok számára elérhetö, mások viszont az euróövezeti és azon kívüli tagországok számára egyaránt hozzáférhetők. Az Európai Stabilizációs Mechanizmus (ESM), a létrehozott Bankunió felügyeleti és szanálási rendszere, a makro- és mikroprudenciális felügyeleti hatóságok alkalmasak a külső krízisek, valamint az egységes piacon kialakuló válsághelyzetek kezelésére. Nélkülük a kilépő tagállam a világpiaci kihívások kezelésében magára marad, és nem érheti el azokat a pénzügyi forrásokat, amelyeket az unió a válságkezelésre hozott létre. A kilépés megakadályozza a közeljövőben létrehozandó Európai Tőkepiaci Unióban való részvételt, a hozzáférést az ESM-ből létrehozandó Európai Monetáris Alap szolgáltatásaihoz, valamint az egyelőre viták kereszttüzében álló transzferunió megvalósuló együttműködéseibe történő bekapcsolódást.

A brexit zűrzavaros folyamata rávilágított mindazokra az alapvető problémákra, amelyekkel az integrációt elhagyó tagállamnak szembe kell néznie. Az elválás technikai részletein túl az igazi kihívást a jövőbeli kapcsolatok jellegének megfogalmazása jelenti. A világ egyik legnagyobb egységes piacához való hozzáférés azonban olyan költségekkel jár, amelyek értelmetlenné tehetik a kiválást. A döntéshozatalban való részvétel nélküli tagság értéktelenebb a teljes tagságnál. Az EU összetett és hatékonyan müködő külkapcsolati rendszerének felváltása egy saját rendszerrel pedig évtizedekre elnyúló feladat, amely a rosszabb alkupozíció miatt szinte biztos, hogy kevesebb előnyt hozhat. 